\title{
膝半月板損傷に対する鏡視下手術の経験
}

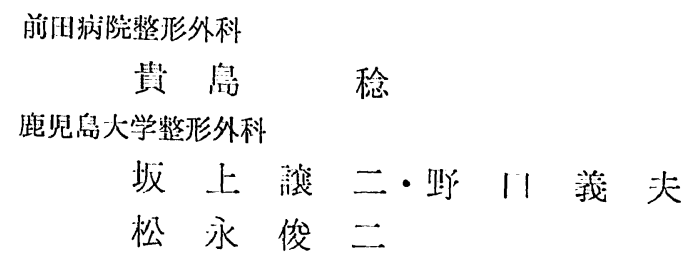

\section{Experience of Arthroscopic Operation in Meniscus Lesions}

by

\author{
Minoru Kijima \\ Orthopaedic Surgery, Maeda Hospital \\ Joji Sakagami, Yoshio Noguchi and Sunji Matsunaga \\ Faculty of Medicine, Kagoshima University
}

\begin{abstract}
It is recently reported that arthroscopic operation can bring about a satisfactory result in meniscus lesion of the knee joint, but this operation is not widely done. Our recent experiences of this procedure is presented. Twenty-seven knee joints were operated through this procedure in twenty-three patients with meniscus lesion. Medial meniscus was removed in thirteen cases, lateral meniscus in seven, lateral and medial meniscus simultaneously in three and lateral meniscus on both sides in one. Five patients showed discoid meniscus. The average time of operation was about a half hour in partial meniscotomy and seventy minutes in total meniscotomy. The patients were discharged from the hospital on the 10 th postoperative day in average. Postoperative results were satisfactory in most of the patients. The conventional surgical procedure can be replaced by the arthroscopic surgery in meniscus lesion.
\end{abstract}

鏡視下半月板切除術は，手術侵裴が小さく関節の機 能回復が早い為, 社会復㸝が早く出来るなど, 従来の 半月板切除術よりも多くの利点がある. 又本術式は, 損傷半月板の部分切除が容易であり, 半月板の㙨能を 温存する事が出来るなどの理由で，近年急速に普及し つつある．私達は，1983 年 1 月より 23 症例， 27 半月 板損傷に対して鏡視下半月板切除術を行なったので報 告する.

$$
\text { 対象 }
$$

対象症例は, 男 14 症例, 女 9 症例の計 23 症例であ る. 年令分布は, 11 才り 70 才で平均 30 才であっ た.

損傷部位は 内倒半月板挰傷 13 症例, 外側半月板損 智 6 症例, 内側, 外側半月板合併損賃 3 症例, 両滕外

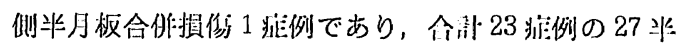
月板挰㑺である.

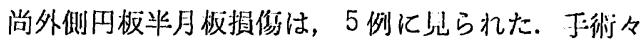

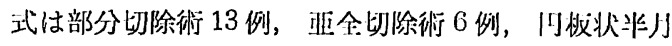
板に刘する北成的兆月板划除術 4 例であった.

$$
\text { 手術 }
$$

関節㳄骨を提伤することなく手術を行なうには，関 節鏡検查手技を十分に修得し遥比な手術器具の 非択 と，テレビモニター下で助手との円深な逊係操作を要 する.

関節鏡は，手術器機之関䬣鏡亡の距朔を保ちやすい 30 度 斜視鏡を使用している，议も頻回に使用する手

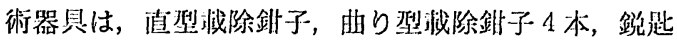
銝子である.その他鏿視下用メニスコトーム 3 種頪, 
鏡視下用ハサミ，スマイリーメニスコトームを用いて いる。コンドロトームは余り份用とは思われない.

于:技にの紧帒は，2点進人法により mobile fragment を一塊として捎出するよう狢」するが, mobile fragmentの然に1分な視野が得られない将 には, fragment をチップとして胤出することであ

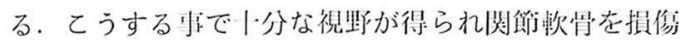
する小なく，短㭙間に于術老終厂する少が出来る．鎲

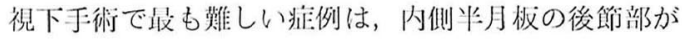
损榎していない辺綄断裂である。このような症例に刘 しては，前的から巾節の一部起切除した後，スマイリ

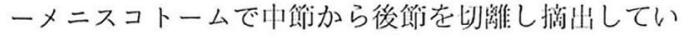
る. 门板状半月板に刘してむ以上の方法で鏡視下手術 は可能であり，関節腔の狄い约夰以外の半月板損佰 は，本術式の適応と考える。

\section{手 術 時 間}

正常型半月板の部分切除は平均 28 分，亜全切除は 平均 70 分であり，门板状半月板に刘する形成的半月 板划除は平此 80 分を要した.

\section{後療法}

術後第 1 月日にドレナージを抜去し, 大煺四頭觔也 ッティング及び可㓰域改普を開始する．松䈎杖使用に て部分荷重又は倒部の痛みが柽ければ全荷重を詐可し ている.

\section{入院 期 間}

属曲 $90^{\circ}$ 以上, 大聴凹頭筋々力 Good となった特 点で，退院作可在与元ている. 全症例 7 日以内でこの 其潐に羊するが，社会的事情による本人の希望を尊重 して退院させている。企症例の平妇入院月数は 12 川 であり，2週間以は入院した 5 例在除くよ9.5 日であ った.

\section{症例}

32 才男性. 左内侧半月板の中節から，後角に及ぶ 水平断裂である. Mobile fragment は半月板前節と 丝骨闺飭面の間に谈頓している。 Fragment の切除 とトリミングを 26 分で蔠了（図1). 術後第 1 日目で ROM $0^{\circ} \sim 120^{\circ}$. 3 月日に大腿四頭筋々力は Good と なり，跛行むなく階段宁降可能となる。術後 14 日で 退院.

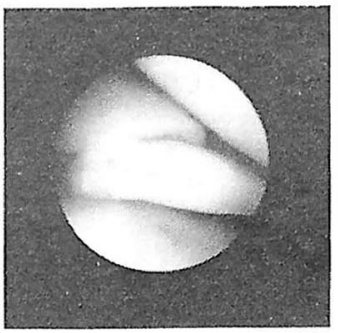

術 㑔

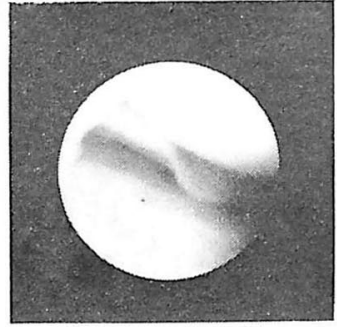

術 後

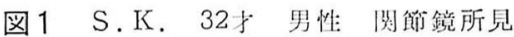

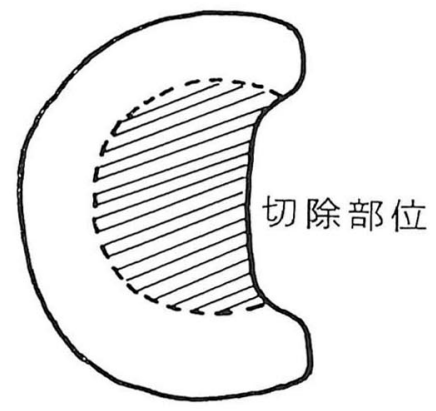

図 2 形成的半月板切除のシエマ

表 1 術 後 評 洒

\begin{tabular}{|c|c|c|}
\hline 徵 侯 & $\begin{array}{l}\text { ロッキング現象 } \\
\text { クッック現象 }\end{array}$ & $\begin{array}{l}\text { 䐂崩机現象 } \\
\text { 水嗹 }\end{array}$ \\
\hline 悑 み & 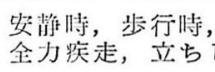 & $\begin{array}{l}\text { 昇降, 正座, 安座, } \\
\text { み, quick turn }\end{array}$ \\
\hline
\end{tabular}

20 才女性. 在外侧円板状半月板の水平断裂である. 図 2 の如く形成的半月板切除を 55 分で終了す. 術後 第 1 日目で ROM $0^{\circ} \sim 100^{\circ}$. 6 日日で大腿四頭筇々力 Good となり 跛行むなく歩行可能となる，術後12日 日で退院.

\section{後 術 成 績}

術後評·仙は，表 1 亿示す患者の主訴を主体として行 なった．術後全く自覚症状のない者が 17 症例， 1 つ でも症状が残存した者が 6 症例である，手術に対する 患者の評仙侸では，全く満足している渾足群 18 症 例. 何らかの主訴を残しているが，再び半月板損賃を生じ た時，再度 鏡視下手術を受けると答えた改善群 3 症 例. 手術結果に不渾足は不変群 2 症例である（表 2 ). 術後主訴の残存した 6 症例中 4 症例は，レ線所見又 は関旍鏡所見で O. A 变化が認められた。

患者䛺㑜で不変となった 1 例は，15才の県下でむ 
表 2 手術に対する患者の棓侹

\begin{tabular}{ll|l} 
桬 & 足 & 18 人 \\
改 & 丵 & $3 \hat{1}$ \\
不 & 変 & 2 人
\end{tabular}

有望は女剣士である. 右内側半月板 L字損賃に対し部 分切除を行ない術後 Locking, Gring-way は消失し たが，運動後に右滕に鈍痛が残存し，かつ腰椎々間板 ヘルニアを合侀している. 残り 1 例は, 円板状半月板 損傷に対し 形成的半月板切除を行なった 16 才の女创 士である. Locking, Giving-way は消失したが， 月 常生活々動で滕関節痛が残存している.

$$
\text { ま と め }
$$

（1）半月板損傷に対する镜視下手術は，手術侵繁 が小さく，関節機能の回復が早い. 又部分切除を行な えば，半月板の機能を温存出来るなど，従来の半月板 切除よりあ传れている.

（2） 円板状半月板切除比対する形成的半月板切除 術は，今後十分な検討を要す。

\section{参 考 文 献}

1) Lanny, L. Johnson: Diagnostic and surgical arthroscopy. Mosby. Tronto London, 1981.
2) Mosaki Watanabe, et al.: Atlas of arhroscopy (Thiro edition) Igaku-Shoin, Tokyo, 1969.

質 問流球人兴 $1: 1 !$ ! 惊光

Disloid type に刘して，杉成的斗今板比除術を行な っていますが, infantili type, infermediato type であれば予後は良いと思いますが, primitive type に対してはいかがお节えでしょうか。

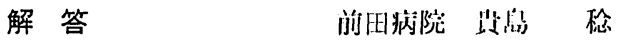

可板状半月板損伤に対しては，原则として断成的将 月板切除を行なっている，術後 Locking 具象は消火

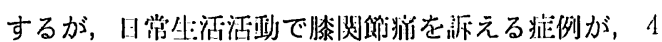
例中 2 例に涊められ，今後検垶を紧す。

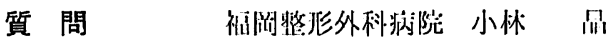
在来のハサミやパンチは弱くてうまくゆかないとと が多いが，何か特别なあのを作って伐闪されている か.

解 答前比病院 出品 稔

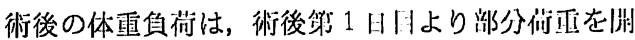

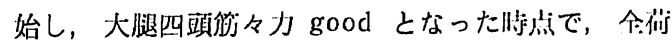
重を訣可している. 